\title{
ADDIN
}

https://journal.iainkudus.ac.id/index.php/Addin

ISSN: 0854-0594; E-ISSN: 2476-9479

Volume 14, Number 2, August 2020: 165-190

DOI: $10.21043 /$ addin.v14i2.8666

\section{Pluralism and Religious Conflict in the Frame of Regional Autonomy in West Sumatra}

\author{
Nunu Burhanuddin \\ Institut Agama Islam Negeri (IAIN) Bukittinggi, Indonesia \\ nunu.burhanuddin@iainbukittinggi.ac.id
}

\section{Dodi Pasilaputra}

Institut Agama Islam Negeri (IAIN) Bukittinggi, Indonesia dodippiainbukittinggi@gmail.com

\section{Hardi Putra Wirman}

Institut Agama Islam Negeri (IAIN) Bukittinggi, Indonesia phardi766@gmail.com

\section{Abstract}

The diversity of ethnicities, races, and religions is a reality in the life of the nation and state, although it is undeniable that there is a potential for conflict. This study aimed to explain the pattern of religious harmony in West Sumatra within the framework of regional autonomy which is adopted from the cultural system and local wisdom. This study used a phenomenological approach to provide accurate conditions of multi-ethnic, cultural, and religious communities. The results showed that the pattern of religious harmony through the resolution of religious conflicts in several regions in West Sumatra was carried out through the alignment of regional autonomy with local customs and culture. Forms of alignment include alignment of school uniforms, equal distribution of sacrificial meat, the presence of baralek, the tradition of manyiriah, interfaith graves between Muslims and Christians, and the application of customary philosophies. This study contributes 
to the theory of a cultural approach based on local wisdom in resolving religious conflicts and strengthening social integration of the community.

Keywords: Religious Conflict, Harmony, Regional Autonomy, Local Wisdom.

\section{Abstrak}

PLURALISME DAN KONFLIK AGAMA DALAM BINGKAI OTONOMI DAERAH DI SUMATRA BARAT. Keberagaman suku, ras, dan agama merupakan realitas dalam kehidupan berbangsa dan bernegara, meski tak disangkal menyimpan potensi konflik di dalamnya. Penelitian ini bertujuan untuk menjelaskan pola kerukunan umat beragama di Sumatra Barat dalam bingkai otonomi daerah yang diadopsi dari sistem budaya dan kearifan lokal. Studi ini menggunakan pendekatan fenomenologis untuk memberikan kondisi akurat dari komunitas multi etnis, budaya, dan agama. Hasil penelitian menunjukkan pola kerukunan umat beragama melalui penyelesaian konflik agama di beberapa daerah di Sumatra Barat dilakukan melalui penyelarasan otonomi daerah dengan adat dan budaya setempat. Bentuk penyelarasan antara lain penyelarasan seragam sekolah, pemerataan daging qurban, kehadiran baralek, tradisi manyiriah, kuburan antaragama antara Muslim dan Kristen, serta penerapan falsafah adat. Kajian ini berkontribusi pada teori pendekatan budaya berbasis kearifan lokal dalam menyelesaikan konflik agama dan memperkuat integrasi sosial masyarakat.

Kata Kunci: Konflik Agama, Kerukunan, Otonomi Daerah, Kearifan Lokal.

\section{A. Introduction}

The concept of religious harmony (kerukunan) in Indonesia has caught people's attention since the new order government made Pancasila as the sole foundation. ${ }^{1}$ The introduction of Pancasila as this sole foundation led to the birth of the Trilogy of Harmony including intrareligious harmony, interreligious harmony, and

${ }^{1}$ Doni Septian, "Pemahaman Nilai-Nilai Pancasila dalam Memperkuat Kerukunan Umat," TANJAK: Journal of Education and Teaching 1, no. 2 (2020): 155-168. 
religio-governmental harmony. ${ }^{2}$ Discussing the interfaith dialogue in the Indonesian context cannot be separated from Mukti $\mathrm{Ali}^{3}{ }^{3}$ as the initiator and the mobilizer of the dialogue and promoted by Alamsyah Ratu Prawiranegara. ${ }^{4}$ The word "kerukunan" is derived from Arabic ruknun with the plural form arkan meaning principle or foundation. ${ }^{5}$ In Indonesian language, the word rukun means: (1) rukun (noun) meaning something that must be fulfilled for the legitimacy of the deed; (2) rukun (adjective) meaning in good and peace condition as in the statement of "hendaknya kita hidup rukun dengan tetangga" (we should live in harmony with neighbors) meaning to be in the state of unity. In this sense, the word merukunkan means to reconcile. ${ }^{6}$ Therefore kerukunan or harmony means to live harmoniously; feeling harmonious; reconcilement and peace. ${ }^{7}$ In the everyday context, the words kerukunan or harmony means peaceful and peace. Hence, it can be understood that the term harmony is used and applied in the everyday world. Harmony is an effort to accomodate and regulate external relations among interreligious or group in social life. ${ }^{8}$ Religious harmony means living in peace and tolerance among similar or different religions through their willingness to accept differences in beliefs and their practice. Religious harmony does not mean correlating the existing religions and merging them into a whole new one. ${ }^{9}$ Religious

${ }^{2}$ Zaitun Abdullah and Endra Wijaya, "Efektifitas Pengaturan Masalah Kerukunan Umat Beragama dalam Peraturan Perundang-undangan di Indonesia," Pandecta: Research Law Journal 11, no. 2 (2017): 113-23, https://doi.org/10.15294/pandecta.v11i2.7830.

${ }^{3}$ Singgih Basuki, "Interreligious Dialogue: From Coexistence to Proexistence (Understanding The Views of Mukti Ali and Hans Kung)," UMRAN: International Journal of Islamic and Civilizational Studies 5, no. 1 (2018): 67-78.

${ }^{4}$ M. Yusuf Asri, "Komunikasi Dialog Merawat Kerukunan Umat Beragama di Indonesia," Jurnal Ilmiah Ilmu Komunikasi 14, no. 2 (2015): 133-53.

${ }^{5}$ Adeng Muchtar Ghazali, "Teologi Kerukunan Beragama dalam Islam (Studi Kasus Kerukunan Beragama di Indonesia)," Analisis 13, no. 1 (2013): 281-302.

${ }^{6}$ Dharmaji Chowmas, "Kerukunan Antar Umat Beragama dalam Pandangan Agama Buddha," Toleransi, 2009.

${ }^{7}$ Masnur Alam, "Harmony in Religious and Cultural Diversity: Case Study of Sungai Penuh City Society," Al-Albab 5, no. 2 (2016): 265-280.

${ }^{8}$ C.W. von Bergen and George Collier, "Tolerance as Civility in Contemporary Workplace Diversity Initiatives," Administrative Issues Journal Education Practice and Research 3, no. 1 (2013), https://doi.org/10.5929/2013.3.1.6.

${ }^{9} \mathrm{~W}$. Bruce Speck, "Relativism and The Promise of Tolerance," Journal of Interdisciplinary Studies Pasadena 10, no. 2 (1998): 67-84. 
harmony is different from syncretism, ${ }^{10}$ which amalgamate the existing religions into a new one. Based on some of the above definition, the term kerukunan or harmony can be interpreted as harmony, compatibility, and balance. Some defining elements that can be drawn from the above concept of harmony are: (1) excessive tension; (2) accomodating two different plans to form a singular system; (3) a process of realizing harmony, compatibility, and balance; (4) cooperating process among various factors in such a way to achieve unity. Clearly, those terms are strongly related when they are associated with the people in different religions, ethnicities, and cultures.

The Minangkabau people are one of the tribes in Indonesia that consists of two regions (darek-regions) with a matrilineal system. Religious harmony, community, and government are the basic to create sustainable development in this country. Interreligious dialogue under the program of Forum Kerukunan Umat Beragama (FKUB, Religious Harmony Forum) of Indonesia can be the modal and platform of religious harmony and religious awarness as intrinsic value of universal humanity. ${ }^{11}$ In the last two years there have been several survey and research institutes that have launched their research results showing that West Sumatra is an area with a low level of tolerance. ${ }^{12}$ The index of harmony in West Sumatra with 19 regencies and cities is still very low, especially relating with the places of worship installations, the implementation of worship together, and the Christmas celebrations. This is due, among others, to: (1) interfaith dialogue tends to be polite, does not touch real problems of the diversity; (2) out of 19 regencies, only 9 regencies (Mentawai, Padang, Padang Pariaman, Padang Panjang, Bukittinggi, Payakumbuh Kapel, Sawahlunto, West

\footnotetext{
${ }^{10}$ H.L. Richard, "Religious Syncretism as a Syncretistic Concept: The Inadequacy of the 'World Religions' Paradigm in Cross-Cultural Encounter," International Journal of Frontier Missiology 31, no. 4 (2014): 209-215.

${ }^{11}$ Khotimah, "Religious Harmony and Government in Indonesia," Religious Harmony 23, no. 1 (2012): 68-69.

${ }^{12}$ Duski Samad, "Intolerance in West Sumatra," 2020, http://www.suarakampus. com/?mod=opini\&se= detil\&id= 245 .
} 
Pasaman, and Pasaman) who have official churches or houses of worship. Meanwhile in 10 other regencies, there are only unofficial prayer houses and houses that are used for worship. ${ }^{13}$ The Ma'arif Institut in 2017 stated that Padang city does not reflect Islamic life in terms of interaction between religious communities. The Setara Institut in 2018 also released survey results that West Sumatra is an intolerance zone. The following is a ranking list of tolerance and intolerance cities in Indonesia from the survey conducted through the method of asking questions and technical triangulation of source and meeting with experts. The ranking had a scale of 1-7. Top 10 most intolerant cities are: Tanjung Balai (score: 2.817), Banda Aceh (score: 2.830), Jakarta (score: 2.880), Cilegon (score: 3.420), Padang (score: 3.450), Depok (score: 3.490), Bogor (score: 3.533), Makassar (score: 3.637), Medan (score: 3.710), and Sabang (score: 3.757$).{ }^{14}$ The Balitbang of the Religion Ministry in its final 2018 report said that West Sumatra is in the $32^{\text {nd }}$ position of the province whose tolerance level is worrying. Pusat Pengkajian Islam dan Masyarakat (PPIM, Islamic and Community Studies Center) Jakarta also mentioned that religion teachers in schools and madrasahs are no longer a source of knowledge for students, and opinions of intolerance are strong enough in their thoughts and actions. According to Duski Samad, the labeling of intolerance has created a perception that is not healthy for the interaction of social life in society. Survey and research found that poor tolerance, the threat of radicalism, and even worse terrorism happened in West Sumatra as forms of socio-cultural and religious anomalies that need in-depth explanation. ${ }^{15}$

Similar conflicts has frequently occurred in West Pasaman. Such as the arson of the Padang Candu church in 2002 because the

${ }^{13}$ Sudarto, "Kerukunan Antar Umat Beragama di Sumbar Tidak Sedang Baik-baik Saja", Covesia.com, https://covesia.com/warnawarni/baca/88402/kerukunan-antar-umatberagama-di-sumbar-tidak-sedang-baik-baik-saja, December 18, 2019.

${ }^{14}$ Inge Klara Safitri, "Jakarta Paling Intoleran Ketiga, Ini Hasil Survei Selengkapnya", Teтро.со, https://metro.tempo.co/read/1153860/jakarta-paling-intoleran-ketiga-inihasil-survei-selengkapnya?page_num=2, December 10, 2018.

${ }^{15}$ Duski Samad, "Intolerance in West Sumatra," http://www.suarakampus. com/?mod=opini\&se= detil\&id= 245, 2020. 
building of the church next to the Jami mosque separated only by a 7 meter road; the protest against Christian Chairperson of the West Pasaman District Court in 2008; the lockdown of Keluarga Kudus Parish Church in 2012; and St Mary Kinasi Church arson on May 4, 2014. Also there was attack to the house of resident who lived in Luhak Nan Duo District in 2012. Initially the house was transformed into a place of worship because the next place of worship was far from the district. The transformation triggered anger of the Muslims, which in the end they forcibly lockeddown the house. In addition, two churches, Stasi Santa Maria Chatolic Church and Theresia Church, located in Kinali District were burned at the same time in 2014. ${ }^{16}$ Other incidents were the conflict on the establishment of the Wonosari chapel, Kinali, West Pasaman. ${ }^{17}$ Interreligious conflict also occurred in Sungai Rumbai District of Dharmasraya in 1995. Another cases are hate speech and religious hate case by Alexander Aan, an employee of Bappeda Dharmasraya in January 2012, ${ }^{18}$ and the case of banning of Stasi Anastashia Sikabau Church community, Pulau Punjung Dharmasraya in 2018. ${ }^{19}$ The study of religious harmony carried out by Laurensius Asliman found that National Human Rights Commission in West Sumatra had not properly played its role in such issues. As a solution, the study of Elly Kristin Debora, Dian Kurnia Anggreta, and Faishal Yasin offered the process of assimilation by practicing interethnic marriage. ${ }^{20}$ This study described the resolution of religious conflicts

\footnotetext{
${ }^{16}$ Ferdi Ferdian, "Fungsi Forum Kerukunan Umat Beragama (FKUB) dalam Sistem Sosial Penciptaan Kerukunan Umat Beragama di Kabupaten Pasaman,” ejournal. iainbukittinggi.ac.id 4, no. 2 (2018): 136-47, http:// ejournal.iainbukittinggi.ac.id/index. php/Islam_realitas/article/view/786.

${ }^{17}$ Nunu Burhanuddin, Ahmad Ali Nurdin, and Muhammad Irfan Helmy, "Religious Conflict and Regional Autonomy in Church Establishment and Islamic Clothing in West Pasaman and Dharmasraya West Sumatera," Indonesian Journal of Islam and Muslim Societies 9, no. 2 (2019): 189-216, https://doi.org/10.18326/ IJIMS.V9I2.189-216.

${ }^{18}$ Della Syahni, "Seminggu Ditahan, Alexander an "Bertobat"”, http://www. andreasharsono.net/2012/01/seminggu-ditahan-alexander-bertobat.html, 2012.

19“Umat Stasi Dilarang Berkumpul, Beribadah di Rumah Meski Tidak Punya Gereja", Suara Wajar FM, https://www.suarawajarfm.com/2018/07/31/25746/umat-stasidilarang-berkumpul-beribadah-di-rumah-meski-tidak-punya-gereja.html, July 31, 2018.

${ }^{20}$ Elly Kristin Debora, Dian Kurnia Anggreta, and Faishal Yasin, "Strategi Masyarakat Multikultural Pasaman Barat Menghindari Konflik," Jurnal Ilmu Sosial Mamangan 2, no. 1 (2013): 22-37.
} 
in several regions in West Sumatra by harmonizing regional autonomy policies with local customs and cultures.

This research used the approach method of religious research. This method provides means of interpreting the answer to the question of why there are different and similar characteristics and why there are the tendencies from the phenomena studied with reasoning arguments. According to Tamene, the reasoning arguments are based on a conceptual framework built on certain theories and approaches. ${ }^{21}$ The informants in research involved the FKUB, pastors, academicians, public figures on Islamic tradition, and the general public who have interacted with citizen's conflicts ini West Sumatra. The data for this research were collected through interview, observation, documentation, and Focus Group Discussion.

A Focus Group Discussion (FGD) is a qualitative research method and data collection technique in which a selected group of people discusses a given topic or issue in-depth, facilitated by a professional and external moderator. This method solicits participants' attitudes and perceptions, knowledge and experiences, to be shared by the interaction with different people. ${ }^{22}$ The data were analyzed based on the views from several informants, then validated by triangulation method. The research conclusion drawn from the analysis and from the combination of the field data (emic) and the researcher's interpretation. ${ }^{23}$

\section{B. Discussion}

\section{Religious Harmony and Functionalism Theory}

In Indonesia the religious harmony is modeled in the Trilogy of Harmony, namely: (a) the internal harmony among people in a similar religion. The internal harmony encompasses the harmony among

\footnotetext{
${ }^{21}$ Ewnetu Hailu Tamene, "Theorizing Conceptual Framework," Asian Journal of Educational Research 4, no. 2 (2016): 50-56.

${ }^{22}$ Peter van Eeuwijk and Zuzanna Angehrn, "How to Conduct a Focus Group Discussion (FGD) Methodological Manual," Swiss Tropical and Public Health Institute/Swiss TPH, 2017.

${ }^{23}$ J.W. Creswell, Research Design: Qualitative, Quantitative, and Mixed Methods Approaches (California: SAGE Publications, Inc., 2014).
} 
schools, ideologies, and sects in a singular religious community; (b) the harmony among different religious communities ${ }^{24}$ includes the harmony between followers of different religions, for example between Muslims, Catholicism, Protestantism, Hinduism, and Buddhism; (c) the harmony between religious communities or between communities and the government. It means the harmony among religious followers and officials with government officials with mutual understanding and respect for their individual works in order to build the better religious community and Indonesian country. Based on the above description, religious harmony is a way of life for humans with different roles and objectives to be maintained together, help each other, to be tolerance, to be not hostile to each other, and to take care of each other. By realizing that these religions are the feature of human social life as an effort to gain salvation for oneself and the wider community in general. Hence, there is no doubt that religion is a system of belief as well as worship performed by humans from various backgrounds as an effort to overcome their problems in life. ${ }^{25}$

According to Peter Clarke, as a belief system adopted by the community, religion becomes a value and reference which has implications for certain functions in life. There are two main functions of religion, namely manifest and latent functions that have implications for human social relations in social life. ${ }^{26}$ The manifest function includes: (a) instilling a pattern of beliefs that determines the nature of relations between humans, and the relationship between humans and their God; this function is also called the doctrinal function; (b) the rituals carried out the symbol and remind the adherents of the doctrines adopted; (c) a set of behavioral norms that are consistent with the doctrine. The other

${ }^{24} \mathrm{Abdul}$ Muid, "Multicultural Education in The Life of Nation, State, and Religion in Islam Perspective," IJIRR 5, no. 1 (2018): 5020-5028.

${ }^{25}$ L.D. Nelson, "Functions and Dimensions of Religion," Sociology of Religion 35, no. 4 (1974): 263-272, https:// academic.oup.com/socrel/article-abstract/35/4/263/159804 8?redirectedFrom=fulltext.

${ }^{26}$ Peter B. Clarke, The Oxford Handbook of the Sociology of Religion, The Routledge Companion to Postmodernism, Third Edition, 2012, https://doi. org/10.4324/9780203792834-6. 
function, namely the latent one, is in the form of hidden and closed functions. This function is allegedly able to create interpersonal conflicts, both among religious adherents and among those with different religions. The latent function has the power to create a feeling of ethnocentrism and superiority which in turn gives rise to fanaticism. These two functions of religion, especially latent functions, lead to the effort to achieve harmony in internal religious communities, among different religious adherents, between religious adherents and government as facilitators and regulators of a religion.

The concept of the Trilogy of Harmony initiated by the government aims to enable the Indonesian people to live together with many differences. This concept is carefully and wisely formulated so that there is no restraint or reduction in human rights in carrying out the obligations of their religious teachings. These three concepts namely the intrareligious harmony, interreligious harmony, and the religio-governmental harmony-is intriguing to measure the diversity of religious, ethnicities, and culture as that found in West Sumatra that became the object of this research. To analyze the pattern of interreligious harmony in West Sumatra, the researcher used several approaches including the paradigm of structural functionalism, the Islamic religious paradigm, and the Christian religious paradigm. The structural functionalism paradigm as stated by Talcott Parsons is the social fact as a "thing" that is different from ideas. ${ }^{27}$

\section{Potential Conflicts and Solutions for Local Cultural Wisdom}

\section{a. Regional Autonomy and Regional Regulation}

The majority of people in West Sumatra are Muslims who adhere to the slogan 'Adat Basandi Syara', Syara'

${ }^{27}$ Bryan S. Turner, “Talcott Parsons's Sociology of Religion and the Expressive Revolution: the Problem of Western Individualism," Journal of Classical Sociology 5, no. 3 (2005): 303-318, https://doi.org/10.1177/ 1468795X05057868. 
Basandi Kitabullah", a tradition based on Islamic law, Islamic law based on the Koran. Through this slogan, the perception of Islam is very strong in Minangkabau. This can be seen from the emergence of Regional Regulations (Perda, Peraturan Daerah) which provide space for the community to implement religious law. The emergence of sharia-based Regional Regulations (Perda) is an implication of the Regional Autonomy regulations that rolled out after the Reformation. Although it is undeniable that the implementation sometimes triggers seeds of conflict. In West Sumatra there are 27 Shariabased regional regulations and are divided into four parts, namely anti-immoral regulations, the obligation to read the Koran, Islamic clothing regulations and zakat regulations, and others. The implementation of several regulations on Islamic clothing in the form of Governor appeal, Regent appeal, Mayor instructions and Regional Regulation allegedly involves all students in the school both Muslim students and non-Muslim students. There is actually a Pasaman ${ }^{28}$ Regional Regulation on Islamic clothing for students and employees. ${ }^{29}$ And then Padang Mayor Instruction No. 451.422/BinsosIII/2005 concerning the Obligation to Wear the Hijab and Muslim Clothing (for residents who embrace Islam) and the recommendation to wear it (for non-Muslims). ${ }^{30}$ The main point of the regulation states, "Every Sekolah Menengah Pertama (SMP, Junior High School), Sekolah Menengah Atas (SMA, Senior High School) student and employee must wear Islamic clothing, while for the general public it is only

${ }^{28}$ Pasaman Regency is one of the districts in the province of West Sumatra, Indonesia. The district capital is located in Lubuk Sikaping. This district has an area of $3,947.63 \mathrm{~km}^{2}$ and has a population of 253,299 according to the 2010 population census.

${ }^{29}$ Surdiyanto, "Regional Regulations at Issue," Kementerian Hukum dan Hak Asasi Manusia RI, http://ditjenpp.kemenkumham.go.id/perkembangan-harmonisasirpp-tahun2010/50-kajian-dan-inventarisasi-perda/157-peraturan-daerah-yang-bernuansa-syariat, n.d.

${ }^{30}$ Heru Permana Putra and Desi Syafriani, “Otonomi Daerah dan Pengaruhnya terhadap Kebijakan Daerah Bernuansa Syariah di Padang," Islam Transformatif 3, no. 2 (2019). 
an appeal." ${ }^{31}$ From the explanation above, it is clear that the Regulations on School Uniform with Hijab and baju koko do exist, and are enforced in public schools in Pasaman, Padang and the others regional in West Sumatra. This enforcement is specifically aimed at Muslim students. However, in practice non-Muslim students as well as non-Muslim workers are also forced or even willing to wear such clothes. There has been no chaos, conflict or open confrontation to the implementation of this regulation from minority students in Pasaman, Padang, and the others regional in West Sumatra.

A similar phenomenon also occurs among Muslim students who attend educational institutions managed by the Catholic Foundation, such as the Don Bosco High School (SMA Don Bosco), Padang. Apart from its openness and diversity, this school is actually a Christian school. SMA Don Bosco is ruled and managed by the Prayoga Padang Foundation, a Catholic foundation engaged in education founded by the Diocese of Padang. In this predominantly Christian environment, religious tolerance is upheld, as shown by the attitude and empathy in providing "space" or the choice of religious knowledge learning according to the religion they profess. The seriousness of students in gaining knowledge, including Islamic religious knowledge-which is not provided by the school-forces Muslim students to seek religious knowledge outside of school. Meanwhile, a different case was found at Xaverius Bukittinggi High School, which provided religious space and Pendidikan Agama Islam (PAI, Islamic Religious Education) learning for Muslim students by bringing in PAI teachers in the school. ${ }^{32}$

${ }^{31}$ Pasaman Regency Regional Regulation Number 22 of 2003 Article 5 concerning Dress Muslim and Muslimah for Students, Students and Employees. This article is a trigger for the emergence of similar articles in articles 6, 7, and 8.

${ }^{32}$ Interview with Aulia Rahman, Lecturer of SMA Haverius Bukittinggi, September 9, 2018. 


\section{b. The Models of Local Wisdom in West Sumatra}

The harmonious intercommunity relations in West Sumatra which consist of various ethnic, and differentreligions have been going on for quite a long time. In general, they live in harmony even though sometimes conflicts occurred.The remnants of religious conflicts are still with the potential for future conflicts. However, the conflict resolution models carried out are to be examined further. There are various efforts and models carried out by Muslims and Christians in West Sumatra in establishing interreligious harmony. This effort involved religious leaders, adat leaders, ninik mamak, and government officials. They all try to build a pattern of harmony. Some of the approaches include understanding the philosophy of Minangkabau life, joint efforts, togetherness in social issues - which include distribution of qurban meat, attendance of baralek, manyiriah, takziah, manjanguak mantah, and interfaith cemetery-and strengthening togetherness through mutual work.

\section{Distribution of Qurbani Meat}

The social relations among interreligious communities in West Sumatra is one of the reasons for the potential of harmony. As a multi-ethnic and religious society, the pattern of adaptation is a must for all communities. This adaptation is proven by the act of mutual understanding, respect and protection, and even gift-giving to one another. It is realized in the practice of social lifesuch as the distribution of qurbani meat from Muslims to the Christian community, wedding invitations, and funeral arrangement. Part of the harmonious relationship between Muslims and followers of other religions in West Sumatra can be seen from the tradition of distributing qurbani meat. The mosques organizing the slaughter of qurban animals also gives the meat to nonMuslims. It is stated by Christian religious leaders in Kinali, Luhak Nan Duo, Koto Baru, and others. "During Eid al-Adha in 
Wonosari, some mosques around our house always distribute the meat to us. The distribution of the meat is carried out by the organizers of the closest mosque to our non-Muslim houses." ${ }^{33}$ It is also confirmed by a Wonosari Muslim that:

"As a form of Muslim concern towards the adherents of other religions, we, Muslims, give one bag of qurbani meat to each house around Wonosari, including to Christians. There is no distinction between Muslim and non-Muslim communities in the distribution of qurbani meat. That is, if the Muslim family gets one bag of meat, then a similar portion is also given to non-Muslim. They usually receive the distribution with joy." ${ }^{34}$

The confirmation of the qurbani meat distribution by mosque administrators to Christian communities in the area is also justified by two church administrators in West Pasaman:

"I really appreciate the concern of the Muslims around Mahakarya for distributing qurbani meat to the Christian community. In general, the community at Mahakarya Church came from transmigrants of Central Java. They came here around 1965. Uniquely, they are divided into two different religious groups, some are Muslim and others are Christian. In this Mahakarya area, they blend in to help each other. ${ }^{35}$ At the time of Eid al-Adha, Christians also help prepare locations and tents for organizing qurbani slaughter. This is a picture of good harmony."36

The similar practice is also found in Dharmasraya as stated by the secreraty of Wali Nagari (rural head) Sungai Rumbai, "The relationship among religious communities in Sungai Rumbai runs harmoniously. The community of different religions, mainly located in Nagari Sungai Rumbai and Sungai Rumbai Timur, works hand in hand in social

\footnotetext{
${ }^{33}$ Interview with Sanuri, Church administrator, October 1, 2017.

${ }^{34}$ Interview with Basri, citizens in Kinali West Pasaman, October 2, 2017.

${ }^{35}$ Interview with Paskalis Riswanto Halawa, Parish Secretary of the Holy Family Mahakarya Church, Oktober 3, 2017.

${ }^{36}$ Interview with Rosmeri Napitupulu, Protestant Clergyman in Pandomuan Nauli Church West Pasaman Church, October 3, 2017.
} 
and communal activities. Gotong royong (community work) is one of the activities that can unite them. It also includes religious activities with social implications such as qurbani worship among Muslims. Usually, Muslims distribute the meat of qurbani animals to Christians around them." ${ }^{37}$ From the information gathered above, it can be concluded that one of the patterns of interreligious harmony in West Pasaman and Dharmasraya is a religious activity that has a relationship with social care and attitudessuch as Eid al-Adha.

\section{The Attendance of Baralek (Wedding)}

One of the community activities that has been carried out from generation to generation is a wedding reception. Wedding ceremonies are social practicefound in any society regardless of ethnicity or religion. As a social tradition, people always want to share happiness with other people. In the Islamic religious tradition, a wedding reception or walimah al-urusy is a tradition the Prophet has taught to his followers The command to hold walimah is delivered the Prophet Muhammad when his daughter, Fatimah, was won by Ali bin Abi Talib r.a. "When Ali proposed Fatimah r.a., Rasulullah saw. said: Indeed it is a necessity for the bride to hold the ceremony." 38 To make wedding reception not fall into prohibited practices, Islam has established norms in organizing the ceremony. Islamic teachings mentioned that the wedding party ceremony should be held with the right intention; provide food; invite friends, neighbors and fellow believers, so as not to invite only rich people; and must attend invitations to those invited. The Prophet said, "If one of you is invited to walimah, let him come to it."39

${ }^{37}$ Interview with Ismi, Secretary of Wali Nagari Sungai Rumbai Dharmasraya, October 4, 2017.

${ }^{38}$ Agus Anwar Pahutar, "Analisis Hadits Tentang Walimah al-'Urusy," Darul Ilmi 7, no. 1 (2019): 45-59.

${ }^{39}$ Imam al-Bukhari, Sahih al-Bukhari (Beirut: Dar al-Fikr, n.d.), 215. 
Meanwhile, Christianity views marriage as an event that began with Adam and Eve. God who created Eve after seeing Adam alone brought her to Adam and married them, so that from that moment they became husband and wife. The next marriage mentioned in the Bible is Isaac's marriage to Rebekah. Jesus and his disciples attended wedding receptions in Christianity when they were invited to attend a wedding in Cana, Galilee. They accepted the invitation, and Jesus even added to the joy of the event. It was stated that, "When the wine began to run out, he miraculously produced extra supplies of the highest quality. After the party, what remains must meet the needs of the bride and her family who are very grateful for some time." [Johanes 2: 3-11]. There is wisdom to learn from the wedding attended by Jesus and his disciples that they did not just come to the the wedding without an invitation. The Bible specifically reports that they were invited [Johanes $2: 1,2]$. In addition, in two illustrations of weddings, Jesus repeatedly spoke of guests who were present because they were invited [Mattius 22: 2-4, 8, 9; also Lukas 14: 8-10].

From the two statements above, it can be said that Islam and Christianity strongly encourage the implementation of wedding reception. Attendance at the reception is based on the invitation of the host or family of the bride and for anyone who is invited, it is an obligation to attend. In practice among people with different religions in West Pasaman and Dharmasraya, it can be described that wedding receptions are one of the means to respect each other and show concern. In these two regencies, as expressed by religious leaders and the community, attending a wedding reception is an activity commonly carried out by each member of the community as a form of relationship and social support. The following is the interview of with community leaders and members:

"Basically,the wedding reception is conducted to inform the status of the bride who has taken a marriage bond. If there is an 
invitation to a wedding reception from Muslims, non-Muslims will fulfill the invitation and vice versa. Here, the reception can be used as a venue for friendship among different religious adherents." 40

"When Christians invite us to a wedding reception, in general Muslims meet the invitation. Usually at every reception, there is a meal. In this case, the host presents two places for meals, namely one place for Muslims the other for non-Muslims this is done to avoid fears of food-which according to Muslims is considered prohibited in their religion." ${ }^{41}$

From some of the information above, it can be understood that the pattern of social relations among different religious communities can be carried out in various ways with the potential to strengthen the harmony. One of which is by attending a wedding reception. In fact it is not uncommon in heterogeneous societies such as Wets Pasaman and Bukittinggi to provides material support for the wedding reception.

\section{The Tradition of Manjanguak Mantah}

Manjanguak Mantah is a funeral ceremony activity carried out by members of the community who are recognized by the bereaved families without kinship boundaries by carrying a pot of rice, eggs, or something else. In West Sumatra this tradition is popular in the Pariaman area, such as in Nagari Tandikek, Patamuan District, Padang Pariaman Regency. ${ }^{42}$ However, this tradition is also found in several other areas as part of an effort to strengthen the brotherhood of fellow community members who do not recognize religious or ethnic differences. In fact, this kind of tradition also applies in the tradition of attending wedding ceremony

${ }^{40}$ Interview with Nasakti, Kepala Seksi Kesejahteraan Rakyat Kecamatan Luhak Nan Duo West Pasaman, October 3, 2017.

${ }^{41}$ Interview with Zulfan Taufik, Lecturer of IAIN Bukittinggi, October 15, 2020.

${ }^{42}$ Y. Trisa, "Tradisi Manjanguak Mantah dan Manjanguak Masak dalam Upacara Kematian di Nagari Tandikek," Thesis Undergraduate, Universitas Negeri Padang, 2011. 
invitations (baralek). ${ }^{43}$ As a part of the social interaction among religious communities, the takziah tradition in Islam or the mourning is carried out in the prevailing religious and customary ways. In this case, if a Muslims die, the neighbors will spontaneously come mourning for takziah or mourning, including the Christian community and vice versa.

\begin{abstract}
"In terms of social relations, the pattern of interaction between religious communities is carried out in various ways such as attending the mourning. In this mourning, people wear generally religious depicted clothing such as baju koko, peci, and kerudung. Such clothing are also worn by Christians who attend mourning in Muslim's funeral." ${ }^{44}$
\end{abstract}

In addition to offering their condolence, these people also prayer for the dead in accordanve with their religious teachings. Even sometimes, Christians also recite al-Fatihah to pray for the dead Muslim. ${ }^{45}$ If Christians die, Muslims also come to their mourning. According to local tradition, people attending the mourning usually bring rice in a container covered in cloth. This mourning tradition is called the tradition of manjanguak mantah. It is done with the intention of alleviating the burden on the families of the deceased. The mourning tradition is also practiced to Christian. Usually, people brings some gift in a containers wrapped in cloth. In the container are $1 \mathrm{~kg}$ of rice and or others. It is as a form of sympathy for the family in mourning. In addition, prayers are also offered in the funeral.

\title{
The Tradition of Manyiriah or Wedding Invitation
}

The tradition of manyiriah is carried out by offering siriah, a type of leaf commonly used by local people in

${ }^{43}$ Interview with Muhiddinul Kamal, Lecture of IAIN Bukittinggi, October 17, 2020.

${ }^{44}$ Interview with Rosmeri Napitupulu, Protestant Clergyman in Pandomuan Nauli Church West Pasaman Church, October 3, 2017.

${ }^{45}$ Interview with Rusmiati, Female, Resident in Kinali, Cristiany Citizens, October $17,2020$. 
traditional ceremeniny or by offering a cigarette by the male family as a form of respect or invitation to attend a wedding and as an expression of condolences to the dead. ${ }^{46}$ After manyiriah, the guest delivers an invitation to attend baralek (wedding ceremony). This manyiriah tradition is part of the Minangkabau culture applicable to all citizens regardless of religion and ethnicity.

The tradition of manyiriah is also practiced by the people of West Pasaman, Dharmasraya, Bukittinggi, Solok, and others. According to one resident, the tradition is a combination of religion and local custom in which all citizens who are given siriah are obliged to attend baralek. This tradition is already established from generation to generation as the medium to strengthen social bond among people with different beliefs.

\section{Interfaith Cemetery between Muslims and Christians}

Islamic concept teaches about glorifying believers and humiliating disbelievers. According to Sharia, it is forbidden to bury the disbelievers in the Muslim cemeteryv because their grave will receive judgement from Allah while the grave of Muslims will receive the grace of Allah and the forgiveness of the $\sin .{ }^{47}$ Therefore, it is not appropriate for both to be in the same location. It is based on the hadith, "I am free from Muslims who are side by side with idolaters.' Then, the Messenger of Allah said, 'So, the fire of the two will not coexist."' The Hadith shows Muslim and non-Muslim graves can not be placed in one location. ${ }^{48}$ As has been done by the Muslims since the time of the Prophet, including what was done by the khulafa ar-Rasyidun and the people after it. It

${ }^{46}$ Interview with Salim Aminullah, A Board Member of FKUB in Dharmasraya, October 5, 2017.

${ }^{47}$ Syihabuddin Ramli, an-Nihayah al-Muhtaj ila Syarh al-Minhaj (n.pl.: n.p., 1984), 3: 8.

${ }^{48}$ Al-Imam an-Nawawi, al-Majmu’ Syarh al-Muhazzab (n.pl.: n.p., n.d.), 5: 489-493. 
has become on going practice a consensus on separating the cemetery of Muslims and non-Muslims. ${ }^{49}$

From the above explanantion, it can be concluded that there is a ban on making the interfaith cemetey between Muslims and non-Muslims. In contrast, interfaith cemetry are found in some areas of West Pasaman such as Luhak Nan Duo and Kinali. This interfaith cemetery is located near to heroes masoleum around Jambak. Such burial models are rarely found in other areas of West Sumatra. According to one resident in Kinali West Pasaman, that the interfaith cemetery has been around for quite some times. It occurs due to a number of issue including the close relationship between Muslim and non-Muslim communities in the area as well as the difficulty of obtaining land that can be allocated for the cemetery of non-Muslims. ${ }^{50}$ Similar information was also conveyed by Christian community leaders that Christians are buried dead bodies at a joint funeral organized by Muslims and non-Muslims. ${ }^{51}$ Besides, it is also common for Muslims to involve in the procession of the burial ground for Christians and vice versa. It is one of the forms of local wisdom that can strengthen the harmony of people in West Pasaman.

The Application of Philosophy "Di Mana Bumi Dipijak, di Situ Langit Dijunjung"

In the course of their life, human beings are bound by the norms and values that apply in society. These binding values become their living philosophies that must be held to achieve success and harmony. Philosophical values that bind people's lives usually become norms. In Minangkabau, the community embraces some philosophical values as their life

\footnotetext{
${ }^{49}$ Ibn Hazm, al-Muhalla, (n.pl.: n.p., 2013), 5: 245-246.

${ }^{50}$ Interview with Zaenal Abidin, Teacher of Majlis Ta'lim in Wonosari West Pasaman, Oktober 15, 2017.

${ }^{51}$ Interview with Sanuri, Church administrator, October 1, 2017.
} 
guidance. "Dima bumi dipijak, disinan langik dijunjuang" is a philosophy of the Minangkabau community meaning " $D i$ mana bumi dipijak, maka di situ langit dijunjung" in Indonesian language or when in Rome, act like a Roman. Regardless of its literal meaning, this string of words has an implied message that everyone must adapt to the community environment and local regulations they live in. ${ }^{52}$ This value is also reflected by Minangkabau people in their business and social life. They adjust their lifestyle with the social context they are in. This philosophical value has a strong relation to people with different social and religious backgrounds. The philosophy "Di mana bumi dipijak, maka di situ langit dijunjung" means that every Minangkabau person including those who live in Minangkabau must adapt to the community environment and local regulations they live in. Therefore, various ethnicities, and religious adherents in Minangkabau must be able to adapt to their community environment and local regulations.

The interrelationship between Christian minority with Muslim majority also occurs in the Dharmasraya that can be described in a mutually respectful interaction and relationship. Such interaction can facilitate mutual understanding among adherents of different religions, especially to rise the understanding among minorities not to impose their will in the presence of a more dominant community. This is as stated by Ismi, as follows, "Christian minority in Sungai Rumbai generally from Batak ethnicity follows the rules applied by Muslim communities here. In matters of worship, they do not force their will to worship in the midst of their own community which is not sufficient to build a house of worship. For these activities, they go to places that have been provided even though they have to

${ }^{52}$ Demina, "Membumikan Nilai Budaya Lokal dalam Membangun Karakter Bangsa", Ta'dib 16, no. 1 (2016): 1-13. 
travel relatively far. This is done to avoid disputes with the dominant member of community." ${ }^{33}$

\section{Conclusion}

Last but not least, it can be stated people in West Sumatra are generally busy with plantation, agriculture, trade, and other economic activities making them more concentrated in developing their welfare. Such economic activities are supported by routine intercommunity activities involving various elements of community. The exchange of information in various economic and social activities emerges the pattern of interaction in a position of mutual need and respects. Hence, the real patterns of interreligious conflic settlement in West Sumatra through the practice of culture, customs, and local wisdom find their right momentum in this multiethnic and religious community.

Some forms of these local wisdom based conflict settlement wisdom are the equal distribution of qurbani meat, the attendance of baralek, the tradition of manjanguak mantah, the tradition of manyiriah, the interfaith cemetery between Muslims and Christians, and the application of adat philosophy. These findings contribute to the theory of local wisdom based cultural approach wisdom and resolving religious conflicts or strengthening social integration of the communities. The patterns of such conflict settlement contribute to the process of strengthening religious harmony in other communities and areas in this country. 


\section{REFERENCES}

\section{Book}

al-Bukhari, al-Imam. Shahih al-Bukhari. Beirut: Dar al-Fikr, n.d.

Clarke, Peter B. The Oxford Handbook of the Sociology of Religion. The Routledge Companion to Postmodernism. n.pl.: n.p., 2012.

Creswell, J.W. Research Design: Qualitative, Quantitative, and Mixed Methods Approaches. California: SAGE Publications, Inc., 2014.

Hazm, Ibn. al-Muhalla. n.pl.: n.p., 2013.

an-Nawawi, al-Imam. al-Majmu'Syarh al-Muhazzab. n.pl.: n.p., n.d.

Ramli, Syihabuddin. an-Nihayah al-Muhtaj ila Syarh al-Minhaj. n.pl.: n.p., 1984.

\section{Journal Article}

Abdullah, Zaitun, and Endra Wijaya. "Efektifitas Pengaturan Masalah Kerukunan Umat Beragama dalam Peraturan Perundangundangan di Indonesia." Pandecta: Research Law Journal 11, no. 2 (2017): 113-23. https://doi.org/10.15294/pandecta. v11i2.7830.

Alam, Masnur. "Harmony in Religious and Cultural Diversity: Case Study of Sungai Penuh City Society." al-Albab 5, no. 2 (2016): 265-280.

Asri, M. Yusuf. "Komunikasi Dialog Merawat Kerukunan Umat Beragama di Indonesia." Jurnal Ilmiah Ilmu Komunikasi 14, no. 2 (2015): 133-53.

Basuki, Singgih. "Interreligious Dialogue: from Coexistence to Proexistence: Understanding the Views of Mukti Ali and Hans Kung." UMRAN: International Journal of Islamic and Civilizational Studies 5, no. 2 (2018): 67-78.

Bergen, C. W. Von, and George Collier. "Tolerance as Civility in Contemporary Workplace Diversity Initiatives." Administrative Issues Journal Education Practice and Research 3, no. 1 (2013). https://doi.org/10.5929/2013.3.1.6. 
Burhanuddin, Nunu, Ahmad Ali Nurdin, and Muhammad Irfan Helmy. "Religious Conflict and Regional Autonomy in Church Establishment and Islamic Clothing in West Pasaman and Dharmasraya West Sumatera." Indonesian Journal of Islam and Muslim Societies 9, no. 2 (2019): 189-216. https://doi. org/10.18326/IJIMS.V9I2.189-216.

Chowmas, Dharmaji. "Kerukunan Antar Umat Beragama dalam Pandangan Agama Buddha." Toleransi, 2009.

Debora, Elly Kristin, Dian Kurnia Anggreta, and Faishal Yasin. "Strategi Masyarakat Multikultural Pasaman Barat Menghindari Konflik." Jurnal Ilmu Sosial Mamangan 2, no. 1 (2013): 22-37.

Demina. "Membumikan Nilai Budaya Lokal dalam Membangun Karakter Bangsa.” Ta'dib 16, no. 1 (2016): 1-13.

Eeuwijk, Peter van and Zuzanna Angehrn. "How to Conduct a Focus Group Discussion (FGD) Methodological Manual," Swiss Tropical and Public Health Institute/Swiss TPH, 2017.

Ferdian, Ferdi. "Fungsi Forum Kerukunan Umat Beragama (FKUB) dalam Sistem Sosial Penciptaan Kerukunan Umat Beragama di Kabupaten Pasaman," ejournal.iainbukittinggi.ac.id 4, no. 2 (2018): 136-47, http:// ejournal.iainbukittinggi.ac.id/index. php/Islam_realitas/article/view/786.

Ghazali, Adeng Muchtar. "Teologi Kerukunan Beragama dalam Islam: Studi Kasus Kerukunan Beragama di Indonesia." Analisis 13, no. 1 (2013): 281-302.

Khotimah. "Religious Harmony and Government in Indonesia." Religious Harmony 23, no. 1 (2012): 68-69.

Muid, Abdul. "Multicultural Education in the Life of Nation, State, and Religion in Islam Perspective." IJIRR 5, no. 1 (2018): 5020-5028.

Nelson, L.D. "Functions and Dimensions of Religion." Sociology of Religion 35, no. 4 (1974): 263-272. https://academic.oup. com/socrel/article-abstract/35/4/263/1598048?redirecte $\mathrm{dFrom}=$ fulltext. 
Pahutar, Agus Anwar. "Analisis Hadits Tentang Walimah al-'Urus." Darul Ilmi 7, no. 1 (2019): 45-59.

Putra, Heru Permana, and Desi Syafriani. "Otonomi Daerah dan Pengaruhnya terhadap Kebijakan Daerah Bernuansa Syariah di Padang." Islam Transformatif 3, no. 2 (2019).

Richard, H.L. "Religious Syncretism as a Syncretistic Concept: the Inadequacy of the 'World Religions' Paradigm in CrossCultural Encounter." International Journal of Frontier Missiology 31, no. 4 (2014): 209-215.

Septian, Doni. "Pemahaman Nilai-nilai Pancasila dalam Memperkuat Kerukunan Umat." TANJAK: Journal of Education and Teaching 1, no. 2 (2020): 155-168.

Speck, W. Bruce. "Relativism and the Promise of Tolerance." Journal of Interdisciplinary Studies Pasadena 10, no. 2 (1998): 67-84.

Tamene, Ewnetu Hailu. "Theorizing Conceptual Framework." Asian Journal of Educational Research, 4, no. 2 (2016): 50-56.

Turner, Bryan S. “Talcott Parsons's Sociology of Religion and the Expressive Revolution: The Problem of Western Individualism." Journal of Classical Sociology 5, no. 3 (2005): 303-318. https://doi.org/10.1177/1468795X05057868.

Zubir, Zaiyardam, and Nurul Azizah Zayzda. "Peta Konflik dan Konflik Kekerasan di Minangkabau Sumatera Barat." Masyarakat Indonesia 36, no. 1 (2017): 53-75. http://ejournal.lipi.go.id/ index.php/jmiipsk/article/view/596.

\section{Website Article}

Safitri, Inge Klara. "Jakarta Paling Intoleran Ketiga, Ini Hasil Survei Selengkapnya.” Tempo.co, https://metro.tempo.co/ $\mathrm{read} / 1153860 /$ jakarta-paling-intoleran-ketiga-ini-hasilsurvei-selengkapnya?page_num=2. December 10, 2018.

Samad, Duski. "Intolerance in West Sumatra." http://www. suarakampus.com $/$ mod=opini\&se $=$ detil\&id $=245.2020$.

Sudarto. "Kerukunan Antar Umat Beragama di Sumbar Tidak Sedang Baik-baik Saja." Covesia.com, https://covesia. 
com/warnawarni/baca/88402/kerukunan-antar-umatberagama-di-sumbar-tidak-sedang-baik-baik-saja. December 18, 2019.

Surdiyanto. "Regional Regulations at Issue." Kementerian Hukum dan Hak Asasi Manusia RI, http://ditjenpp.kemenkumham. go.id/perkembangan-harmonisasirpp-tahun-2010/50kajian-dan-inventarisasi-perda/157-peraturan-daerahyang-bernuansa-syariat, n.d.

Syahni, Della. "Seminggu Ditahan, Alexander an Bertobat." http:// www.andreasharsono.net/2012/01/seminggu-ditahanalexander-bertobat.html. 2012.

"Umat Stasi Dilarang Berkumpul, Beribadah di Rumah Meski Tidak Punya Gereja." Suara Wajar FM, https://www.suarawajarfm. com/2018/07/31/25746/umat-stasi-dilarang-berkumpulberibadah-di-rumah-meski-tidak-punya-gereja.html. July 31, 2018.

\section{Thesis}

Trisa, Y. "Tradisi Manjanguak Mantah dan Manjanguak Masak dalam Upacara Kematian di Nagari Tandikek." Thesis Undergraduate, Universitas Negeri Padang, 2011.

\section{Interview}

Interview with Aminullah Salim, member of FKUB in Dharmasraya, April 9, 2018.

Interview with Aulia Rahman, Lecture of SMA Haverius Bukittinggi, September 9, 2018.

Interview with Basri, Citizens in Kinali West Pasaman, October 2, 2017.

Interview with Ismi, Secretary of Wali Nagari Sungai Rumbai Dharmasraya, October 4, 2017.

Interview with Muhiddinul Kamal, Lecture of IAIN Bukittinggi, October 17, 2020. 
Interview with Nasakti, Kasi Kesra Kecamatan Luhak Nan Duo West Pasaman, October 3, 2017.

Interview with Paskalis Riswanto, Parish Secretary of the Holy Family Mahakarya Church, October 3, 2017.

Interview with Rosmeri Napitupulu, Protestant Clergyman in Pandomuan Nauli Church West Pasaman Church, October 3, 2017.

Interview with Rusmiati, Christiani Citizens in Kinali West Pasaman, October 1, 2017.

Interview with Sanuri, Church administrator, October 1, 2017.

Interview with Zaenal Abidin, Teacher of Majlis Ta'lim in Wonosari West Pasaman, October 2, 2017.

Interview with Zulfan Taufik, Lecturer of IAIN Bukittinggi, October 15, 2020. 